\title{
Kekerasan Seksual sebagai Taktik Perang Kongo: Antara Impunitas Hukum Nasional dan Pemberlakuan Statuta Roma
}

\author{
Indah Ardhita Udit; Novianti; Rahayu Repindowaty Harahap \\ Fakultas Hukum Universitas Jambi \\ *Coresponding author: Indahardhita1@gmail.com
}

$\begin{array}{ll}\text { Submission } & : 04 \text { Juli } 2021 \\ \text { Revision } & : 09 \text { Agustus } 2021 \\ \text { Publication } & : \text { 12 Oktober } 2021\end{array}$

\begin{abstract}
Sexual violence during conflict has become a crucial issue in the realm of Humanitarian Law. In its development, this form of violence is carried out systematically, spreads, and is often carried out under orders. This article discusses how the enforcement of humanitarian law can be implemented properly in the Congo war. The results of the study show that the effectiveness of Congo's national law should have played a role in this incident. Weak national law enforcement results in the failure of the function of law as a guide to justice, resulting in impunity. As a preventive measure, the implementation of the Rome Statute is imperative. The statute states that systematic and widespread sexual violence is a form of crime against humanity and a violation of humanitarian law.
\end{abstract}

Keyword: sexual violence; tactic of war; prevention of sexual violence in conflict

\begin{abstract}
Abstrak
Kekerasan seksual pada saat konflik telah menjadi isu yang krusial di ranah Hukum Humaniter. Dalam perkembangannya, bentuk kekerasan tersebut dilakukan secara sistematik, menyebar, serta seringkali dilakukan di bawah komando. Artikel ini membahas bagaimana penegakan hukum humaniter mampu diimplementasikan dengan baik dalam perang Kongo. Hasil kajian menunjukan bahwa efektifitas hukum nasional Kongo seharusnya
\end{abstract}


mengambil peran dalam peristiwa tersebut. Lemahnya penegakan hukum nasional mengakibatkan gagalnya fungsi hukum sebagai petunjuk keadilan sehingga terjadi impunitas. Sebagai upaya pencegahan, penerapan Statuta Roma menjadi keharusan. Statuta menyatakan bahwa kekerasan seksual yang sistematik dan menyebar tersebut adalah bentuk kejahatan terhadap kemanusiaan serta pelanggaran terhadap hukum humaniter.

Kata Kunci: kekerasan seksual; taktik perang; pencegahan kekerasan seksual dalam konflik.

\section{A. Pendahuluan}

Artikel ini membahas mengenai penggunaan kekerasan seksual sebagai taktik perang pada Perang Kongo serta mengulas bagaimana upaya pencegahan kekerasan seksual tersebut sebagai taktik perang dalam perspektif Hukum Humaniter.

Mohammed Bedjaoui mengatakan bahwa hukum humaniter tidak dimaksudkan untuk melarang perang, tetapi ditujukan untuk memanusiawikan perang. ${ }^{1}$ Sehingga dibuat suatu aturan yang memberikan perlindungan terhadap pihak yang terlibat langsung dan tidak langsung dalam perang, dan mencegah dilakukannya perang yang tidak menaati prinsipprinsip kemanusiaan.

Sebagai bentuk perlindungan terhadap pihak-pihak yang terlibat secara langsung dan tidak langsung dalam perang, hukum humaniter juga mengatur penggunaan cara-cara dan alat-alat yang kenyataannya terus berkembang. Hukum humaniter merumuskan instrumen hukum yang mengatur tentang batasan dan larangan terkait alat dan cara-cara

Mohammed Bedjaoui, Modern Wars: Humanitarian Challenge, A Report for the Independent Commission on International Humanitarian Issues, Zed Books Ltd., London, 1986, hal. 2 sebagaimana dikutip dalam Rhona K.M. Smith et al., Hukum Hak Asasi Manusia, Pusham UII, Yogyakarta, 2008. hal. 335

Uti Possidetis: Journal of International Law, Vol. 2, No. 3 (2021) 
berperang yang dituangkan di dalam Pasal 35 Ayat (1) sampai Ayat (3) Protokol Tambahan II tahun 1977.

Berdasarkan ketentuan tersebut, para pihak yang bersengketa boleh memilih cara atau alat berperang dengan tidak terbatas. Namun, membatasi senjata-senjata dan taktiktaktik yang dapat digunakan dalam perang untuk menghindari penderitaan yang tidak perlu serta pelarangan penggunaan cara atau alat yang dapat mengakibatkan kerusakan berat terhadap alam. ${ }^{2}$

Menurut Organisasi Kesehatan Dunia (WHO), Kekerasan seksual adalah setiap tindakan seksual atau upaya untuk mendapatkan tindakan seksual atau tindakan lain yang ditujukan terhadap seksualitas seseorang dengan menggunakan paksaan, oleh siapa pun tanpa memandang hubungannya dengan korban, dalam pengaturan apa pun. ${ }^{3}$

Secara umum definisi kekerasan seksual adalah setiap perbuatan merendahkan, menghina, menyerang, dan/atau perbuatan lainnya terhadap tubuh, hasrat seksual seseorang, dan/atau fungsi reproduksi, secara paksa, bertentangan dengan kehendak seseorang, yang menyebabkan seseorang itu tidak mampu memberikan persetujuan dalam keadaan bebas, karena ketimpangan relasi kuasa dan/atau relasi gender, yang berakibat atau dapat berakibat penderitaan atau kesengsaraan secara fisik, psikis, seksual, kerugian secara ekonomi, sosial, budaya, dan/atau politik. Hukum Humaniter secara tegas mengatur bahwa cara dan alat berperang tidak boleh mengakibatkan luka yang berlebihan dan penderitaan yang tidak perlu serta wajib menaati prinsip-prinsip kemanusiaan.

2 Umar Suryadi Bakry. Hukum Humaniter Internasional sebuah pengantar.Jakarta: Prenadamedia Group. 2019. hal. 5.

3 Violence against women. https://www.who.int/news-room/factsheets/detail/violence-against-women. diakses pada 10 september 2021

Uti Possidetis: Journal of International Law, Vol. 2, No. 3 (2021) 
Namun pada masa perang di Republik Demokratik Kongo pada tahun 1996-1997 dan 1998-2003, telah terjadi kejahatan terhadap kemanusiaan dan kejahatan perang khususnya kekerasan seksual. Kekerasan seksual tersebut disusun secara sistematis dan teratur yang dilakukan sebagai bagian dari taktik perang oleh para tentara pemberontak untuk menekan keadaan psikologis lawannya dengan mempermalukan dan menjatuhkan moralnya.. ${ }^{4}$ Diana Millillo dari Universitas Connecticut mengatakan bahwa Selama berabad-abad, pemerkosaan terhadap perempuan telah digunakan sebagai taktik perang untuk memajukan posisi politik, ekonomi, sosial, atau agama satu kelompok di atas yang lain. Pemerkosaan massal yang sistematis menghancurkan perempuan secara individu dan menghancurkan tatanan keluarga dan komunitas. ${ }^{5}$

Perang Kongo mengakibatkan jutaan korban jiwa meninggal ataupun terlantar. Laporan yang menyebutkan pelanggaran-pelanggaran serius yang terjadi salah satunya ialah kekerasan seksual. Selama periode Perang Kongo I (19961997), Office Of The United Nations High Commissioner For Human Rights melaporkan berbagai kejahatan perang dan kejahatan kemanusiaan yang dilakukan oleh Forces Armées Zaïroses (FAZ) atau Tentara Nasional Zaire (nama sebelum RDK) terkhususnya pada bagian kekerasan seksual yang dilakukan secara menyebar dan sistematis serta bertujuan untuk menciptakan terror, seperti; pemerkosaan di depan

4 Tiara Triajiramadhani. Peran International Criminal Court (ICC) Dalam Menghentikan Kejahatan Kemanusiaan Di Republik Demokratik Kongo Tahun 2012-2016. Skripsi Sarjana Ilmu Sosial Dan Ilmu Politik Universitas Muhammadiyah Yogyakarta, Yogyakarta, 2017. hal. 12.

5 Diana Millillo Affilia. Journal of Women and Social Work, Rape As At Tactic Of War: Social and Psychological Perspective, 2006, University Of Cxonnecticut, Storrs. hal. 1. 
publik, pemerkosaan yang dilakukan secara beramai-ramai, pemerkosaan yang sistematik, mutilasi genital dan kanibalisme ialah teknik-teknik yang digunakan dalam perang terhadap warga sipil. ${ }^{6}$

Sedangkan pada Perang Kongo II (1998-2003) serupa dengan kejahatan kejahatan pada Perang Kongo I, pada Perang Kongo II banyak kasus tentara-tentara yang berupaya saling mengungguli dalam hal kekejaman kekerasan seksual yang mereka targetkan kepada korbannya dengan cara memasukkan benda-benda ke genital korban seperti; tongkat-tongkat, botolbotol, pisang, tongkat kayu yang dilumuri lada atau cabai dan laras senjata api. ${ }^{7}$ Komandan para tentara pun sering "menawarkan" pemerkosaan sebagai hadiah kepada pasukan mereka.. ${ }^{8}$

Kejahatan-kejahatan yang terjadi pada masa Perang Kongo I dan II merupakan pelanggaran terhadap Hukum Humaniter dan merupakan kegagalan negara untuk melindungi warga nya yang tidak terlibat di dalam perang. Karena setiap negara memiliki kewajiban untuk menjamin dan menghormati hak asasi manusia, melindungi dan menegakkannya di negara masing-masing. ${ }^{9}$

6 OHCHR. DEMOCRATIC REPUBLIC OF THE CONGO, 1993-2003. Report of the Mapping Exercise documenting the most serious violations of human rights and international humanitarian law committed within the territory of the Democratic Republic of the Congo between March 1993 and June 2003, Jenewa, 2010, hal. 318.

7 Ibid, hal. 319.

8 Ibid, hal. 320.

9 Retno Kusniati. Sejarah Perlindungan Hak Hak Asasi Manusia Dalam Kaitannya Dengan Konsepsi Negara Hukum, Jurnal Ilmu Hukum Vol. 4 Issue 5, 2011, hal. 86. 


\section{B. Pembahasan}

\section{Penegakan Hukum Terhadap Penggunaan Kekerasan Seksual sebagai Taktik Perang}

Sebelum kita membahas lebih lanjut mengenai penegakan hukum, perlu kita ketahui lebih dahulu, dalam keadaan yang seperti apakah kekerasan seksual dapat digolongkan sebagai taktik atau metode perang? ICRC menyatakan bahwa kekerasan seksual digolongkan sebagai metode berperang ketika terdapat tindakan sebagai berikut:

"terhubung dengan komando, dan praktik yang sistematik... (dan) pemerkosaan atau kekerasan seksual harus dilakukan secara menyebar; tindakan-tindakan yang tergolong dalam kekerasan seksual harus dalam lingkup atau menargetkan kelompok populasi yang memiliki hubungan dengan konflik bersenjata; (dan) tindakan-tindakan tersebut harus dilakukan di bawah tanggung jawab otoritas dan/atau pembawa senjata, bahkan jika mereka tidak melakukannya sebagai hasil dari perintah atau perintah yang eksplisit."10

Kekerasan seksual dapat dinyatakan sebagai kejahatan terhadap kemanusiaan apabila perbuatan tersebut dilakukan secara meluas yang ditujukan kepada suatu kelompok nonkombatan. Dalam Pasal 8 Ayat (2) huruf b Statuta Roma juga menjelaskan tentang pelanggaran berat ketika kejahatan berupa perkosaan, perbudakan seksual, pemaksaan prostitusi, pemaksaan kehamilan dan lainnya dilakukan oleh pihak yang sedang berkonflik. Tindakan seperti ini menurut Konvensi Jenewa disebut juga sebagai pelanggaran hukum internasional.

Dalam Konvensi Jenewa 1949 terdapat prinsip aut dedere aut judicare yang berarti; negara memiliki kewajiban untuk memproses secara hukum perseorangan yang melakukan tindak pidana berat, dalam situasi negara lain tidak melakukan

10 Janet Benshoof. The Other Red Line: The Use of Rape as an Unlawful Tactic of Warfare. Global Policy, Volume 2 Issue 2, 2014. hal. 147. 
pemrosesan hukum atau tidak memintakan ekstradisi terhadap perseorangan tersebut. ${ }^{11}$ Prinsip ini memberikan yurisdiksi universal kepada negara-negara lain untuk mengadili pelaku tindak pidana dengan karakter grave breaches. ${ }^{12}$

Menurut penulis, hukum yang pertama kali digunakan untuk melakukan penindakan kejahatan tersebut ialah hukum nasional negara itu sendiri. Hukum nasional didahulukan untuk diterapkan terhadap kejahatan-kejahatan internasional yang terjadi di wilayah negara yang bersangkutan. ${ }^{13}$ Apabila negara yang bersangkutan tidak mau atau tidak mampu melaksanakan peradilannya maka perkara tersebut dapat diadili oleh pengadilan internasional maupun negara lain.

Dalam hukum internasional terdapat dua peradilan permanen, yaitu International Court of Justice (ICJ) dan International Criminal Court (ICC). ICJ merupakan badan peradilan yang berdiri bersama PBB pada tahun 1945 dan subyek peradilannya ialah negara, sedangkan ICC merupakan institusi independen yang kedudukannya sebagai international order yang memiliki visi untuk mewujudkan cita-cita dari masyarakat internasional yang bersifat mendasar, utama, dan universal serta subjeknya adalah individu. Seorang individu disebut sebagai subjek dari peradilan ICC, karena Pasal 4 Ayat (1) Statuta Roma menjelaskan bahwa individu adalah subjek hukum internasional yang memiliki international personality. Dengan demikian ICC dapat melakukan berbagai international legal capacity dalam rangka pelaksanaan fungsinya.

ICC berwenang untuk mengadili pelaku-pelaku kejahatan internasional termasuk kekerasan seksual. Akan tetapi ICC

11 Purnomo A. Chandra. Pengantar Yurisdiksi Universal dan Penerapannya Dalam Hukum Humaniter. Direktur Hukum dan PI Polkam Kementerian Luar Negeri. hal. 18.

12 Ibid.29.

13 Sefriani. Yurisdiksi ICC terhadap Negara non Anggota Statuta Roma 1998. Jurnal Hukum. Vol 14, No. 2, 2007, hal. 323. 
hanya dapat menangani kasus-kasus yang terjadi setelah 1 Juli 2002, dikarenakan Statuta Roma 1998 baru berlaku efektif setelah diratifikasi oleh 60 negara. ICC hanya dapat mengadili individu yang berasal dari negara peserta, individu dari negara bukan peserta yang melakukan kejahatan di wilayah negara peserta, serta individu dari negara bukan peserta yang mengakui yurisdiksi ICC melalui deklarasi ad hoc sesuai dengan yang dituangkan dalam Pasal 12 Statuta Roma 1998.14

Kejahatan terhadap kemanusiaan dan kejahatan perang yang terjadi pada perang kongo I dan II terjadi sebelum adanya ICC. Penulis menyimpulkan bahwa kejahatan harus diadili oleh pengadilan nasional di RDK atau diadili oleh negara lain dalam upaya implementasi yurisdiksi universal terhadap kejahatan dengan karakter grave breaches. Untuk itu, Republik Demokratik Kongo, melalui Kode Pengadilan Militer RDK 1972 mengatur tentang penegakan dan penjatuhan sanksi atas kejahatan yang dilakukan oleh anggota militer, termasuk pengaturan mengenai tindakan kekerasan seksual, tetapi tidak secara eksplisit mengatakan pelarangan terhadap kekerasan seksual. Namun, menyatakan bahwa hukum pidana Kongo juga berlaku terhadap anggota militer. ${ }^{15}$

Pemerintah RDK kemudian memperbaharui Kode Pengadilan Militer melalui Kode Pengadilan Militer dan Kode Pidana Militer RDK tahun 2002. Dalam instrumen ini masih belum mengatur larangan-larangan dasar terkait kekerasan seksual. Aturan tersebut hanya menyebutkan bentuk-bentuk kekerasan seksual. Hal itu dapat ditemui pada pasal 169 yang menjelaskan bahwa bentuk-bentuk kekerasan seksual seperti perbudakan seksual, pemaksaan prostitusi, penghamilan paksa, pemaksaan sterilisasi, dan bentuk kekerasan seksual yang lain

14 Ibid, hal. 321.

15 Human Rights Watch. Seeking Justice: The Prosecution of Sexual Violence in the Congo War. Volume 17 No. 1A. 2005, hal. 27.

Uti Possidetis: Journal of International Law, Vol. 2, No. 3 (2021) 
saat dilakukan secara sistematik dan meluas terhadap rakyat sipil merupakan kejahatan terhadap kemanusiaan. ${ }^{16}$

Pembaharuan tersebut dilakukan guna memenuhi kewajiban RDK sebagai anggota PBB dan sebagai negara yang meratifikasi Konvensi Jenewa 1949. Tidak hanya itu, RDK mempunyai kewajiban untuk memastikan bahwa kode pidananya menuntut kejahatan perang dan kejahatan terhadap kemanusiaan, termasuk pemerkosaan dan kekerasan seksual, sesuai dengan ketentuan perjanjian. ${ }^{17}$

Berdasarkan argumentasi hukum diatas, pemerintah Kongo wajib untuk memberikan kepastian hukum melalui penegakan hukum atas kekerasan seksual yang terjadi dinegaranya. Namun, perwujudan penegakan hukum selama masa perang dan sesudah perang hanya sedikit sekali yang dilakukan, impunitas yang tinggi mempengaruhi rendahnya persentase penegakan hukum atas kejahatan-kejahatan yang terjadi pada masa Perang Kongo I dan II.

Faktor yang menyebabkan gagalnya penegakkan hukum nasional oleh pemerintah Kongo ialah susahnya identifikasi korban ataupun pelaku maupun mencari tahu dimana pelaku berada, korban takut akan retribusi atau secara khusus diancam dengan kekerasan jika mereka berusaha untuk menuntut pelaku, korban tidak tahu bahwa mereka bisa menempuh jalur hukum dan mencari keadilan, korban merasa malu, trauma dan takut dengan stigma yang akan diberikan oleh masyarakat, dan bahkan korban bahkan sering diperintah oleh polisi untuk tetap diam. ${ }^{18}$

Masalah-masalah umum pada sistem peradilan juga mempengaruhi rendahnya penegakan hukum seperti; korupsi

\footnotetext{
16 Ibid, hal. 28.

17 Ibid, hal. 27.

18 Ibid, hal. 37
}

Uti Possidetis: Journal of International Law, Vol. 2, No. 3 (2021) 
yang marak terjadi di bidang hukum (penyuapan hakim atau petugas-petugas lain yang terkait untuk mempengaruhi hasil investigasi dan hasil persidangan) serta kurangnya staff yang berkualitas, dan dukungan logistik maupun organisasi yang efisien. ${ }^{19}$

Lebih dari tiga juta orang menjadi korban meninggal dunia akibat perang Kongo. Namun, berdasarkan penelitian yang dilakukan oleh OHCHR, penegakan hukum terhadap kejahatan perang dan kemanusiaan yang telah terjadi, hanya terdapat 2 kasus saja yang telah diadili oleh Pengadilan Militer Kongo. Praktik impunitas yang tinggi serta banyaknya keterlibatan asing mempengaruhi sistem peradilan di RDK. ${ }^{20}$

Pada tahun 2004, akhirnya ICC melakukan investigasi pertama atas kejahatan perang dan kejahatan terhadap kemanusiaan yang terjadi di RDK sejak 1 Juli 2002 dengan fokus daerah utama ialah Kongo Timur. ICC menangkap 6 orang tersangka, dan semuanya adalah pemimpin para kelompok bersenjata. Keenam orang tersebut ialah Thomas Lubanga Dylio (Pemimpin Union des Patriotes Congolais), Germain Katanga (Komandan The Force de Resistance Patriotique en Ituri), Bosco Ntaganda (Wakil Kepala Staff dan Komandan Operasional Forces Patriotiques pour la Liberation du Congo), Callixte Mbarushimana (Sekretaris Eksekutif Forces Democratiques pour la Liberation du Rwanda) tuduhan tidak terkonfirmasi, Sylvestre Mudacumura (Komandan Tertinggi Forces Democratiques pour la Liberation du Rwanda) yang hingga saat ini masih dalam pengejaran, dan Mathieu Ngudjolo Chui

19 Ibid, hal. 42.

20 UN Mapping Reports. Climate of Impunity in the DRC. OHCHR, hal. $1-2$.

Uti Possidetis: Journal of International Law, Vol. 2, No. 3 (2021) 
(Pemimpin Front des nationalists et Integrationnites) yang kemudian dibebaskan. ${ }^{21}$

Berdasarkan uraian diatas dapat kita lihat bahwa penegakan hukum terkait penggunaan kekerasan seksual pada waktu perang ialah dengan melalui hukum nasional negara itu sendiri dan kegagalan fungsi hukum di RDK menghasilkan impunitas yang tinggi sehingga kejahatan terkait bentukbentuk kekerasan seksual yang sistematik dan menyebar tidak ditegakkan sebagaimana mestinya.

\section{Upaya Pencegahan Kekerasan Seksual sebagai Taktik Perang dalam Perspektif Hukum Humaniter}

Tingginya praktik impunitas terhadap kejahatan perang serta kejahatan terhadap kemanusiaan yang terjadi di RDK pada masa Perang Kongo I dan II maupun pada masa seperti Perang Sipil Sierra Leone (1991-2002), Liberia (1989-2003), dan Yugoslavia lama (1992-1995), masyarakat internasional mulai menyadari bahwa urgensi terhadap penggunaan kekerasan seksual sebagai taktik perang harus mendapatkan perhatian penuh dan harus dilakukan upaya-upaya yang bertujuan untuk mencegah terjadinya hal yang sama di kemudian hari dan meningkatkan posisi kejahatan kekerasan seksual tidak hanya dianggap sebagai collateral damage seusai perang. ${ }^{22}$ Tentu saja aturan-aturan yang bertujuan untuk mencegah hal tersebut terjadi harus dibuat secara keseluruhan tidak hanya sebagian agar tidak terjadi impunitas akibat kekosongan hukum yang ada.

21 ICC Investigation, icc-cpi.int/drc diakses pada Senin, 26 April 2021 pukul 00.39 WIB.

22 United Nations. Sexual Violence: a Tool of War, Outreach Programme On The Rwanda Genocide And The United Nations. New York. 2014, hal. 1 . 
Sebelumnya, larangan melakukan kekerasan seksual saat waktu perang telah lebih dulu diatur dalam instrumeninstrumen hukum lama seperti; Lieber Code 1863, Konvensi Jenewa 1949 dan Protokol Tambahan I dan II 1977. Namun, instrumen hukum yang ada dianggap belum cukup untuk mengatasi permasalahan ini. Oleh karena itu bentuk pencegahan yang dapat dilakukan dengan cara mengakui kekerasan seksual yang dilakukan secara sistematik dan menyebar sebagai kejahatan perang dan kejahatan terhadap kemanusiaan.

Langkah baik yang pernah masyarakat internasional lakukan dalam melakukan pencegahan ini ialah pada pasca Perang Dunia ke-2. Pasca perang dunia ke-2 dibentuk peradilan internasional yaitu Nuremberg Tribunal 1945 dan Tokyo Tribunal 1946 untuk mengadili penjahat perang, namun kedua peradilan tersebut memiliki output yang berbeda, sehingga disimpulkan bahwa kedua peradilan ini tidak bersifat independen dan netral.23

Pada 1992, DK PBB mulai memperhatikan tindakan kekerasan seksual yang dilakukan secara sistematik dan menyebar saat perang di bekas wilayah Yugoslavia dan menyatakan bahwa kekerasan seksual yang terjadi pada saat itu adalah kejahatan internasional yang harus diatasi. Atas perhatian oleh DKK PBB tersebut membuat Statuta ICTY 1993 menjadikan pemerkosaan sebagai kejahatan terhadap kemanusiaan. Begitu pula Statuta ICTR 1994 juga menegaskan bahwa pemerkosaan sebagai kejahatan perang dan kejahatan terhadap kemanusiaan. ${ }^{24}$

Bentuk-bentuk kekerasan seksual yang bersifat sistematik dan menyebar sebagai kejahatan perang dan sebagai kejahatan terhadap kemanusiaan kemudian diakui secara

\footnotetext{
23 Sefriani, Op.Cit., hal. 317.

24 United Nations, Op.Cit., hal. 2.
}

Uti Possidetis: Journal of International Law, Vol. 2, No. 3 (2021) 
internasional melalui Statuta Roma 1998 yang berlaku sejak tahun 2002. Dan ditindak lanjuti dengan dibentuknya peradilan internasional yaitu International Criminal Court (ICC) yang merupakan institusi independen yang bertugas untuk mengadili kejahatan-kejahatan internasional seperti; genosida, kejahatan terhadap kemanusiaan, kejahatan perang, dan kejahatan agresi.

Namun, pencegahan melalui instrumen-instrumen hukum tersebut masih belum cukup untuk menangani kekerasan seksual pada masa perang. Maka dari itu, DK PBB mengeluarkan Resolusi 1325 (2000) yang isinya memanggil negara-negara anggota untuk meningkatkan partisipasi wanita dalam "pencegahan dan resolusi konflik" dan dalam "pemeliharaan dan promosi perdamaian serta keamanan". DK PBB menyatakan kepada pihak-pihak yang terlibat dalam konflik bersenjata untuk mematuhi Hukum Internasional yang melindungi hak wanita dan anak-anak sipil serta menyertakan kebijakan dan prosedur yang melindungi para wanita dari kejahatan berbasis gender seperti pemerkosaan dan serangan seksual.

Kemudian terdapat Resolusi 1820 (2008) yang secara tegas mengatur larangan penggunaan kekerasan seksual sebagai taktik perang yang ditujukan kepada warga sipil. lalu juga terdapat resolusi 1888 (2009) yang berisi langkah-langkah terperinci untuk lebih melindungi wanita dan anak-anak dari kekerasan seksual dalam situasi konflik seperti meminta Sekretaris Jenderal PBB untuk menunjuk perwakilan khusus untuk memimpin dan mengkoordinasi pekerjaan PBB terkait isu tersebut, dan untuk mengirimkan tim ahli dalam mengatasi situasi yang membutuhkan perhatian tertentu.

Terdapat pula resolusi nomor 1960 (2010) yang mengatur tentang permintaan kepada Sekretaris Jenderal untuk membuat daftar pihak-pihak yang dicurigai melakukan atau bertanggung jawab atas dugaan kejahatan pemerkosaan 
pada masa perang. Untuk memperkuat pengawasan dan pencegahan kekerasan seksual pada saat konflik, DK PBB membentuk resolusi nomor 2106 (2013). Serta juga membentuk resolusi DK PBB Nomor 2122 (2013) berupa pengulangan akan pentingnya keterlibatan perempuan dalam pencegahan, resolusi, dan pembangunan perdamaian pada saat konflik. ${ }^{25}$

Bentuk implementasi dari resolusi-resolusi yang telah dikeluarkan oleh DK PBB dilakukan melalui pembentukan program-program dibawah agensi-agensi milik PBB seperti; penyatuan misi-misi PBB dalam melawan kekerasan seksual pada saat konflik dibawah satu agensi khusus yaitu UN Action Against Sexual Violence in Conflict yang berfokus pada peningkatan koordinasi dan pertanggungjawaban, memperkuat pemrograman dan advokasi, dan mendukung upaya-upaya nasional untuk mencegah kekerasan seksual dan memberikan respon yang efektif terhadap kebutuhan korban kekerasan seksual.

Kemudian Sekretaris Jenderal PBB juga aktif melakukan kampanye yang bernama UNiTE to End Violence against Women yang bertujuan untuk mencegah dan mengeleminasi kekerasan terhadap perempuan dan anak-anak di dunia, dalam waktu peran dan damai. Kampanye ini bekerja sama dengan agensiagensi PBB yang lain termasuk individu, rakyat sipil dan pemerintahan untuk mengakhiri kekerasan terhadap perempuan dalam segala bentuk.

Dalam upaya mewujudkan Resolusi 1888, Sekretaris Jendral PBB juga menunjuk perwakilan PBB di saat konflik dan berniat untuk mengakhiri impunitas untuk pelaku dan mencari keadilan untuk korban. Melakukan mobilisasi kepemimpinan politik untuk mengatasi masalah ini, memperkuat koordinasi dan menjamin respon yang lebih jelas dari sistem PBB,

25 Ibid, hal. 3

Uti Possidetis: Journal of International Law, Vol. 2, No. 3 (2021) 
meningkatkan pengenalan pemerkosaan sebagai taktik perang, dan menekankan kepemilikan, kepemimpinan, dan pertanggungjawaban nasional dalam upaya untuk mengakhiri kasus ini.

\section{Penutup}

Berdasarkan uraian diatas, Artikel ini menyimpulkan bahwa, penegakan hukum terkait penggunaan kekerasan seksual pada waktu perang ataupun kejahatan-kejahatan yang melanggar Hukum Internasional ialah harus diadili melalui hukum nasional terlebih dahulu dan apabila hukum nasional dianggap tidak mampu, maka dapat diadili oleh negara lain atau pun ICC sepanjang kejahatan yang dilakukan belum di adili dan termasuk dalam golongan grave breaches.

Lalu, untuk mencegah penggunaan kekerasan seksual pada waktu perang tidak berakhir sebagai collateral damage, maka oleh PBB pada pasca perang di Yugoslavia Lama dan Rwanda membentuk peradilan sementara/Ad-Hoc seperti ICTY dan ICTR. Kemudian juga lahir perjanjian internasional baru yaitu Statuta Roma 1998 sekaligus badan peradilan yang bersifat independen yang kita kenal dengan sebutan International Criminal Court (ICC) yang bertugas untuk menangani kejahatan-kejahatan serius seperti; genosida, kejahatan perang, kejahatan terhadap kemanusiaan, dan kejahatan agresi.

Selanjutnya, Dewan Keamanan PBB juga mengeluarkan tujuh resolusi yang mana satu diantaranya yaitu Resolusi 1820 (2008) secara jelas mengatur larangan penggunaan kekerasan seksual sebagai taktik perang yang ditujukan kepada warga sipil dan untuk mengakhiri impunitas yang selama ini dinikmati oleh pelaku. 


\section{Referensi}

\section{Buku}

Bakry, Umar Suryadi. Hukum Humaniter Internasional sebuah pengantar.Jakarta: Prenadamedia Group. 2019.

Haryomataram KGPH, Pengantar Hukum Humaniter. Rajawali Pers, Jakarta, 2012.

Human Rights Watch, Seeking Justice: The Prosecution of Sexual Violence in the Congo War, Volume 17 No. 1A, 2005.

Smith, R.K.M. et al., Hukum Hak Asasi Manusa, Pusham UII, Jakarta, 2008.

Starke, J.G. Pengantar Hukum Internasional, Terjemahan Bambang Iriana Djajaatmadja, Edisi Ke Sepuluh Jilid II, Jakarta: Sinar Grafika, 1992.

\section{Artikel/Jurnal/Karya Ilmiah}

Benshoof, J. The Other Red Line: The Use of Rape as an Unlawful Tactic of Warfare. Global Policy: Volume 2 Issue 2, Global Justice Center, New York, 2014.

Chandra A. P. Pengantar Yurisdiksi Universal dan Penerapannya Dalam Hukum Humaniter, Direktur Hukum dan PI Polkam Kementerian Luar Negeri.

Kusniati, Retno. Sejarah Perlindungan Hak Hak Asasi Manusia Dalam Kaitannya Dengan Konsepsi Negara Hukum. Jurnal Ilmu Hukum Vol. 4 Issue 5, 2011.

Millillo, D. Rape As A Tactic Of War: Social And Psychological Perspective, Affilia: Journal of Women and Social Work, University of Connecticut, Storrs, 2006.

Sefriani. Yurisdiksi ICC terhadap Negara non Anggota Statuta Roma 1998. Jurnal Hukum, Volume 14 No. 2, 2007.

Triajiramadhani, T. Peran International Criminal Court (ICC) Dalam Menghentikan Kejahatan Kemanusiaan Di Republik Demokratik Kongo Tahun 2012-2016. Skripsi 
Sarjana Ilmu Sosial Dan Ilmu Politik Universitas Muhammadiyah Yogyakarta, Yogyakarta, 2017.

United Nations, Sexual Violence: a Tool of War, Outreach Programme On The Rwanda Genocide And The United Nations, New York, 2014.

UN Mapping Reports, “Climate of Impunity in the DRC", OHCHR

\section{Website}

https://id.m.wikipedia.org/wiki/taktik perang"TaktikPerang". di akses 04 Februari 2020.

https://www.icc-cpi.int/drc "ICC Investigation". di akses 26 April 2021

Violence against women. https://www.who.int/news-room/factsheets/detail/violence-against-women. diakses pada 10 september 2021 